\title{
CONCEPT CARTOON IN PROBLEM-BASED LEARNING: A SYSTEMATIC LITERATURE REVIEW ANALYSIS
}

\author{
Siti Najihah Binti Jamal (D), Nor Hasniza Binti Ibrahim (D), Johari Bin Surif $(\mathbb{D}$ \\ Universiti Teknologi Malaysia (Malaysia) \\ sitinajihab93@gmail.com,p-norbaniza@utm.my,johari_suri@utm.my
}

Received September 2018

Accepted December 2018

\section{Abstract}

Concept cartoon teaching strategy have the potential to increase creativity and innovation as well as the students' interest in understanding concepts. It is considered as a method that encourages students to continue exploring the issues raised and seeking solutions. This concept cartoon lesson is very suitable to be applied in the field of Science, Technology, Engineering and Mathematics which is often regarded as an abstract and difficult field. Therefore, it is becoming a necessity to see how far the cartoon concept in learning has been implemented in schools. This systematic literature review analysis aims to focus on the similarities and differences such as the objective used, the methodology used and the findings of the study. The study article was selected through a database of various types of journals according to keywords. Keywords used in the search are Concept Cartoon AND comic AND Problem-based learning. The search has been limited between 2009 and 2017. The nine of articles have been chosen to be analyzed based on the four steps in systematic literature review. The four steps included frame a question, run a search, the abstract and tittle of individual papers have to be read and the information need to be abstract from selected set of final articles. The results of the systematic literature review analysis can be concluded on recent research and previous research that cartoon concept teaching strategy is very effective in enhancing creative thinking as well as cultivating students' interest in Science, Technology, Engineering and Mathematics.

Keywords - Concept cartoon, Comic, Systematic literature review analysis, Problem-based learning, Teaching strategy.

\section{To cite this article:}

Jamal, S.N.B., Ibrahim, N.H.B., \& Surif, J.B. (2019). Concept cartoon in problem-based learning: A systematic literature review analysis. Journal of Technology and Science Education, 9(1), 51-58. https://doi.org/10.3926/jotse.542

\section{Introduction}

In the 21st century, the education system within the country and abroad really emphasizes teaching and learning strategies. This is because effective teaching and learning strategies are key to the progress of the education system. In this regard, the role of teachers is crucial to the success of the Ministry of Education through the diversity of teaching and learning strategies in the classroom. Among the teaching 
and learning strategies that teachers can highlight are problem-based learning, inquiry-based learning and project-based learning. Indeed, traditional or conventional teaching strategies are irrelevant to being applied in the classroom in which it is not aligned with the goals of the 21 st century education system seeking innovation in teachers' teaching. Thus, the role of teachers in ensuring the teaching and learning strategies that are used can attract students to interest in Science, Technology, Mathematics and Engineering subjects (Jamal, Ibrahim, Surif, Suhairom, Abdullah \& Jumaat, 2017).

To attract the attention of students is not so easy but teachers can find initiatives using visual teaching materials such as cartoon concepts or comic books supported by problem-based learning approaches throughout the teaching and learning process takes place in the classroom. Problem-based learning through the cartoon concept or comic book is one of the teaching and learning strategies where teachers provide scenarios related to everyday life that are converted into a cartoon or comic concept. However, there is a little research on problem-based learning through this cartoon or comic concept. Therefore, a meta-analysis of the study is needed to examine the extent of problem-based learning through cartoon or comics concepts carried out by past researchers.

\section{Literature Review}

Nowadays, teacher-centred instruction is in decline, while the student centered approaches is more dominant and aiming to encourage them to learn by doing and living started to take place in the curricula. One of these methods is problem-based learning (Balim, Turkoguz, Ormanci, Kacar, Evrekli \& Ozcan, 2014). Problem-based learning is defined as an activity from everyday life that can lead to scenario issues (Balim, Inel-Ekici \& Ozcan, 2016). They stated that the issue of this scenario leads to an active learning process where students need to learn how to solve problems independently. The problem-based learning begins after the teacher gives the students a scenario problem taken from everyday life problems (Sahin, 2010). After the problem identification process is done, the student should try to solve the problem scenario using the previous knowledge and existing knowledge (Sockalingam, Rotgans \& Schmidt, 2011). In this regard, the concept of cartoon is appropriate in linking past knowledge and knowledge as it can stimulate the ideas of students, the thinking skills of students can be challenge and the students can develop their understanding through supportation by concept cartoon (Naylor \& Keogh, 2013).

The concept of cartoon is the most popular forms of instructional media which is also abundantly and easily found is cartoon or illustration humour (Subhan \& Lilia, 2010). This is because ideas transmitted through cartoon is easily understood namely through the action of the cartoon character (Subhan \& Lilia, 2010). Besides that, the cartoon concept has succeeded in showing its importance in modern teaching and learning strategies (Koutnikova, 2017) through some previous studies. In this regard, there are many past studies that have identified the effects of using cartoon concepts in learning on discussion skills (Naylor \& Keogh, 2013), learning fun (Narayan, 2016), students' attitudes and interests (Kaptan \& Izgi, 2014) and student achievement (Murtiningrum, Ashadi, Mulyani, 2013). According to the study of Demirci and Ozyurek (2017), the effectiveness of using cartoon concepts in anatomy learning has given a positive impact on critical thinking skills among students. The study was also supported by the study of Yin and Fitzgerald (2017) which states that the concept of cartoon has a significant impact on critical thinking and student learning achievement. Although there are many studies related to problem-based learning and cartoon concepts, but there is still a lack of research on cartoon concepts in problem-based learning. Therefore, this systematic literature review analysis study is aimed to identify the similarities and differences such as the objective used, the methodology used and the findings of the study.

\section{Methodology}

Research articles are selected through a database of various types of journals based on keywords used. Keywords used in the search are Concept Cartoon AND Comic AND Problem-based Learning. For the purpose of obtaining the latest study, the search has been limited between 2009 and 2017. A total of 9 studies have been selected to be analyzed based on the four steps in systematic literature review analysis. The figure 1 have shown the four steps in systematic literature review analysis based on Basu (2017): 


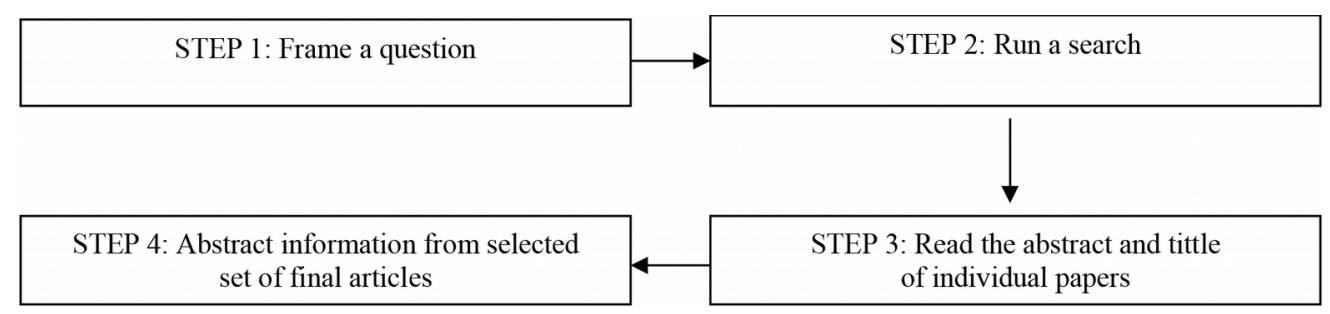

Figure 1. The four steps in systematic literature review analysis

For the first step which is framing a question. For framing an answerable question in a systematic literature review, the researcher used the PICO framework. PICO is an acronym for "Participant-Intervention-Comparator-Outcomes". In this research paper, participant refers to individuals or population of interest to researcher. Intervention needs to be as broadly or as narrowly defined keeping only the intervention of researchers' interest. Comparator refer to either the intervention versus placebo or interventions versus conventional treatment or interventions and no treatment are compared. The outcome that researcher is interested can be narrowly or broadly defined based on the objective of the literature review analysis. The outcome is narrowly defined, then literature review analysis is only restricted to that outcome. The researcher is interested to find out if concept cartoon in problem-based learning is enhancing students' achievement, students' thinking skills, students' active learning and also motivation among students. Then, the researcher stated the question in PICO as follows:

- P: Students (age 7 years and above), both sexes, all ethnicity, all nationality.

- I: Concept cartoon or comic in problem-based learning.

- C: Problem-based learning approaches.

- O: Students achievement, students' thinking skills, students' active learning and students' motivation.

The second step which is run a seach of the literature databases. After the researcher have decided the PICO, the researcher conducted a search of the literature databases. This helped researcher to identify the appropriate search terms. These search terms are arranged using Boolean Logic related controlled vocabulary, symbols of truncation or expansion, and placement of the terms in different sections of a reported study. In Boolean Logic, the researcher use the connectors, "AND", "OR", and "NOT" in various combinations to expand or narrow down search results and findings. For example as shown below;

- "Students" AND "Concepts cartoon in Problem-based learning" will find only those articles that have BOTH students AND concepts cartoon in problem-based learning as the subject topics.

- "Students" OR "Concepts cartoon in problem-based learning" will find all articles that have EITHER "Students" OR "Concepts cartoon in problem-based learning" in their subject topics, so the number of results returned will be larger.

- "Students" NOT "Concepts cartoon in problem-based learning" will find only those articles that contain "Students" but will exclude all articles that have "Concepts cartoon in problem-based learning" as their topic area.

For the third step which is selected the articles for literature review analysis by reading titles, abstracts and full texts. The researcher set up a scheme where the researcher decided to select and reject the articles for literature review analysis. For example, the article is relevant for the study question, the article does not discuss the outcome that is of interest to this research and the article is published outside of the date range. Because of that only 9 articles have been chosen to be analysed. For the last step is abstract the information from articles. In this matter, the researcher abstract the information from articles and then put all those needed information into table synthesis matrix according to subthemes: authors, research 
objective, sample or respondent, research design, analysed data and the findings. From that table analysis, the researcher can make some similarities and differences in the nine studies.

\section{Results}

There are some similarities and differences in the nine studies. All of these similarities and differences are divided into three parts of the results, such as the objective used, the methodology used and the findings of the study.

\subsection{Objective Used}

In studies of Balim et al. (2016), Fatimah and Widiyatmoko (2015), Balim, Celiker, Turkoguz and Kacar (2013), Murtiningrum et al. (2013), Balim, Celiker, Kacar, Evrevkli, Turkoguz, Inel et al. (2012), Inel and Balim (2011), Birisci and Metin (2010), their study aims to identify the effectiveness of using cartoon concepts in problem-based learning among school students. However, there are two studies, Balim et al. (2014) and Inel and Balim et al. (2013) studies have the same purpose in exploring the views of teachers and students on problem-based learning through cartoon concepts.

\subsection{Metodology Used}

Overall, the design used in the 9 of studies was divided into three design which are quarsi experiment, case study and descriptive study. Most previous research using the quarsi experiment design aimed to see the effectiveness of using cartoon concepts in problem-based learning rather than other learning approaches (Balim et al., 2016; Fatimah \& Wadiyamoko, 2015; Inel \& Balim, 2011) in line with Noraini (2010) which stated that the experiment design is best suited to finding relationships between independent variables (using cartoon concepts and problem-based learning) with dependent variables (achievement, attitude and perception). In addition, the selection of the quarsi experiment design was also due to the emphasis on the comparison between two or more sets of group data, the experiment design provided the researchers with confidence that the results of observations were due to the influence of the program (Chua, 2014) cartoon concepts or just the effects of problem-based learning itself.

In addition, for a case study study aims to deeply deepen a case (Chua, 2014) such as how the process of using problem-based learning through the cartoon concepts takes place and why using problem-based learning through cartoon concepts (Balim et al., 2014; Inel \& Balim 2013; Murtiningrum et al., 2013 Balim et al., 2012; Birisci \& Metin, 2010). In addition, Inel and Balim (2013) used a descriptive research design to identify students' perceptions of the use of cartoon concepts in problem-based learning. The design of this study is very relevant to the study as it is more open to describing the true view of the student on the use of the concept of the cartoon (Lans \& Van der Voordt, 2002).

It is found that $44.44 \%$ of the total study (Balim et al., 2016; Fatimah \& Widiyatmoko, 2015; Murtiningrum et al., 2013; Inel \& Balim, 2011) are focused on quantitative data analysis whether statistically descriptive or inferential statistics. However, there are five studies (Balim et al., 2012, 2013, 2014; Inel \& Balim, 2013; Birisci \& Metin, 2010), which is $55.56 \%$ analyzing data using a qualitative approach. In addition, $55.56 \%$ of researchers from Birisci and Metin (2010), Balim et al. (2012, 2013, 2014, 2016) enjoy using survey respondents among primary school students and teachers. Meanwhile, $44.44 \%$ of respondents in high school students and teachers only (Inel \& Balim, 2011; Murtiningrum et al., 2013; Inel \& Balim, 2013; Fatimah \& Widiyatmoko, 2015).

\subsection{Findings of Research}

The similarity in Balim et al. (2016), Murtiningrum et al. (2013), Inel and Balim (2011) and Birisci and Metin (2010) are those with independent variables which is using cartoon concepts in learning but dependent variables for each of their studies are different. One of the dependent variables is inquirybased learning skills and knowledge daily life (Balim et al., 2016), creative thinking and abstract thinking (Murtiningrum et al., 2013) and motivation (Inel \& Balim, 2011). The findings of Balim et al. (2016) said 
that there was a significant difference $(\mathrm{p}=.031, \mathrm{p}<.05)$ in post-group tests on inquiry-based learning skills. Whereas, there was no significant difference $(\mathrm{p}=.496, \mathrm{p}=>$. 05$)$ in post-group tests on daily life knowledge. Furthermore, the study of Murtiningrum et al. (2013) shows that every $51 \%$ of students have low levels of ability to think abstractly and think creatively through comics. In addition, the findings of Inel and Balim (2011) find out that there are significant differences in experimental groups using the concept of cartoon in problem-based learning on student motivation.

Meanwhile, the finding of Fatimah and Widiyatmoko (2015) show the results of science comic media based on problem-based learning assessed by experts to determine the feasibility of media, language and material aspects. It turns out that the science comics built by them meet the most appropriate criteria for all three aspects. Percentage assessment on media aspect was $95.83 \%, 99.07 \%$ (language) and $95.37 \%$ (material). In fact, researchers get $100 \%$ of students' perceptions on a small scale on science comic media based on problem-based learning. Similarly, $96.57 \%$ of students' perceptions on a large scale on science comic media based on problem-based learning. The findings from Fatimah and Widiyatmoko (2015) study also show the increase in student learning outcomes before pre-test $(50.28 \%)$ and after post-test $(80.97 \%)$.

After analyzing, the finding exists in Balim et al. (2012, 2013) and Birisci and Matin (2010) where they emphasized the findings of the study on building a cartoon concepts module in problem-based learning. However, there is a little difference in the aspect of content activity in the construction of the cartoon concepts module. For example, Balim et al. (2013) has developed a cartoon concepts module by providing a scenario of heat spread ways. The four cartoonists need to discuss the problem of scenarios that occur in everyday life. However, the cartoonization of scenarios is not given and is hidden from the student's knowledge. This is because it allows students to understand the problem of scenarios, describe the problem of the scenario, identify the problem of the scenario, identify existing knowledge that needs to be used and suggest answers to the problem. In this case, the problem scenario is converted into a cartoon concepts. Furthermore, the content activity in Balim et al. (2012) is similar to Balim et al. (2013) which is a problem scenario translated in the form of a cartoon concepts. However, there is a little difference in which there are three scenario problem activities included and each problem is different. Furthermore, the study of Birisci and Metin (2010) presents the construction of a cartoon concepts module titled "Earth's crust composed of what?". That study differs from Balim et al. $(2012,2013)$ as researchers use multimedia software such as inserting sound elements and movements on cartoon characters. In fact, researchers also integrate the 5e model into the cartoon concepts. Inel and Balim (2013) and Balim et al. (2014) share similarities in which they carry out semi-structured interviews about their views on the use of cartoon concept in problem-based learning. The difference was from the respondents' intake in aspect of students (Inel \& Balim, 2013) and teachers (Balim et al., 2014). These findings indicated one of Balim et al. (2013) taken from students;

"It was entertaining. Lesson went well"

"T participated in lesson less previously but now I participated in lesson mostly"

"This method helped me for learning well"

In addition, the following also shows the results of interviews from teachers (Balim et al., 2014);

"Concept cartoons might be a good way of helping students define the problem better. Concept cartoons are useful in this situation"

"It had an effect by visualizing because use of concept cartoons in class helped students remember visually"

\section{Discussions}

Overall, quarsi experiment are also more favourable design used in quantitative method from the previous studies. It is because quarsi experiment is the most suitable design when researchers want to identify the effect or the effectiveness of concept cartoon in teaching and learning (Demirci \& Ozyurek, 2017) when 
the random distribution can not be done in the process of selecting respondents (Chua, 2014). The choice of the researchers is more to qualitative and quantitative perspectives. But the most widely used is a qualitative method. This is because there are many things that happen in this world can not be explained by simply referring to quantitative data (Chua, 2014). So that, the researchers used qualitative method to get in depth information data. Based on the approach of all the above studies, researchers are less fond of the combination of quantitative and qualitative data analysis or known as mixed method. However, the mixed method can be used to obtain better data collection and to meet the needs of researchers in problem-based learning through the cartoon concepts.

Furthermore, almost all studies have been conducted on primary school students and teachers. This is due to cartoon concepts in teaching and learning for attracting the interest of primary students in science subject. In this case, children are more likely to use visual tools that encourage them to participate actively in classroom (Naylor \& Keogh, 2013). However, a few studies have been conducted on high school students. Actually, researchers can apply in secondary schools because students at secondary school level are exposed to problem solving questions related to daily life. This statement is aligned with Balim et al. (2016) who have said that problem-based learning, generally used in higher education, requires students to use higher order thinking skills in learning environments. In fact, secondary science students also experience difficulties in visualizing the concept of science as long as the science concept is an abstract nature of topic (Akani, 2017; Ghani, Ibrahim, Yahaya \& Surif, 2017). In order to use effectively for secondary students, concept cartoons can be integrated to problem-based learning environment as it can provide alternative views, help students to visualize and solve the problem (Balim et al., 2016).

Based on the students' views and teachers' views, it was concluded that the concept cartoon assisted problem-based learning method provided students with opportunity to learn science subject by making fun, active participitation in learning process, learned the lesson permanently and also provide the teachers with chance to experience the benefits of problem-based learning modules (Inel \& Balim, 2013; Balim et al., 2014). According to Gafoor and Shilna (2013), studied indicated that concept cartoons can reduce stress by making fun and encourage students towards active participitation in classroom. By comparison of literature review, Birisci and Metin (2010) also mentioned that concept cartoon provides students learned very well, meaningful and permanently.

Last but not least, mostly the studies are focused on determine the effectiveness of using cartoon concepts in problem-based learning on achievement, student motivation, student misconceptions, active participate in argumentation, critical and creative thinking. It is supported by the others researchers such as Demirci \& Ozyurek (2017) who are used the cartoon concepts to identify the effects of using cartoon concepts in astronomy subjects on critical thinking skills. However, all the above studies still lacked of emphasis on how the concept of using the cartoon concept in problem-based learning towards student thinking. Therefore, studies on the use of cartoon concepts in problem-based learning on students' thinking must be further enhanced in giving a overview of the teaching and learning situation for improvement purposes.

\section{Conclusion}

In conclusion, this concept paper has shown a pattern of recent studies on problem-based learning through cartoon concepts for Science subjects at school level. Design of quasi experiment study, case study and descriptive study are the design of the study used in the studies. For the respondent, primary students or teachers are widely used in the studies. In addition, analysis data based on quantitative and qualitative perspectives. Therefore, the use of cartoon concepts in problem-based learning greatly affects students and teachers in terms of teaching and learning. This is because it improves abstract thinking, creative, critical, ability to solve problems, motivation and achievement of student learning outcomes as well as encourage active participation in the classroom through group discussions or individuals. 


\section{Declaration of Conflicting Interests}

The authors declared no potential conflicts of interest with respect to the research, authorship, and/or publication of this article.

\section{Funding}

I thank to National Funds Grantt with reference nombor PY/2016/06512 to support and publish this paper in International Conference on Creative and Innovative Technology 2018.

\section{References}

Akani, O. (2017). Identification of the area of students difficulties in chemistry curriculum at the secondary school level. International Journal of Emerging Trends in Science and Technology, 4(4), 5070-5077. https://doi.org/10.18535/ijetst/v4i4.04

Balim, A.G., Inel-Ekici, D., \& Ozcan, E. (2016). Concept cartoons supported problem based learning method in middle school science classrooms. Journal of Education and Leraning, 5(2), 272-284. https://doi.org/10.5539/jel.v5n2p272

Balim, A.G., Turkoguz, A., Ormanci, U., Kacar, S., Evrekli, E., \& Ozcan, E. (2014). Teachers' views about problem-based learning through concept cartoons. Journal of Baltic Science Education, 13(4), 458-468.

Balim, A.G., Celiker, H.D., Turkoguz, S., \& Kacar, S. (2013). Concept cartoon samples integrated to PBL scenario towards matter and heat unit. Mediterranean Journal of Educational Research, 14a, 865-873.

Balim, A.G., Celiker, H.D, Kacar, S., Evrevkli, E., Turkoguz, S., Inel et al. (2012). Concept cartoons integrated problem-based learning in science and technology education: An activity sample dance of the heated particules. Western Anatolia Journal of Education Science, 3(5), 68-87.

Basu, A. (2017). How to conduct meta-analysis: A basic tutorial. Available at: https://ir.canterbury.ac.nz/bitstream/handle/10092/14582/conduct-meta analysis $\% 281 \% 29$.pdf? is Allowed $=\mathrm{y} \&$ sequence $=2$

Birisci, S., \& Metin, M. (2010). Developing an instructional material using a concept cartoon adapted to the 5E model: A sample of teaching erosion. Asia-Forum on Science Learning and Teaching, 11(1), 1-16.

Chua, Y.P. (2014). Kaedah penyelidikan (3rd ed.). Malaysia: McGraw-Hill

Demirci, F., \& Ozyurek, C. (2017). The effects of using concept cartoons in astronomy subjects on critical thinking skils among seventh grade student. International Electronic Journal of Elementary education, 10(2), 243-254. https://doi.org/10.26822/iejee.2017236119

Fatimah, F., \& Widiyatmoko, A. (2015). Pengembangan science comic berbasis problem-based learning sebagai media pembelajaran pada tema bunyi dan pendengaran untuk siswa smp. Unnes Science Education Journal, 4(1), 700-710.

Gafoor, K.A., \& Shilna, V. (2013). Role of concept cartoons in chemistry learning. Available at: https://files.eric.ed.gov/fulltext/ED545358.pdf

Ghani, I.B.A., Ibrahim, N.H., Yahaya, N.A., \& Surif, J. (2017). Enchancing students' HOTS in laboratory educational activity by using concept map as an alternative assessment tool. Chemistry Education Research and Practise, 18, 849-874. https://doi.org/10.1039/C7RP00120G

Inel, D., \& Balim, A. G. (2013). Concept cartoons assisted problem based learning method in science and technology teaching and students' views. Procedia-Social and Behavioral Sciences, 93, 376-380.

https://doi.org/10.1016/j.sbspro.2013.09.206 
Inel, D., \& Balim, A.G. (2011). The effect of concept cartoons assisted problem based learning method on motivation about science learning of secondary students. Usak Universitesi Sosyal Bilimler Dergisi, 2(1), 169-188.

Jamal, S.N., Ibrahim, N.H., Surif, J., Suhairom, N., Abdullah, A.H., \& Jumaat, N.F. (2017). Understanding of STEM education among chemistry teachers in district of melaka tengah. Man in India, 97(12), 101 108.

Kaptan, F., \& Izgi, U. (2014). The effect of use concept cartoons attitudes of first grade elementary students towards science and technology course. Procedia-Social and Behavioral Sciences, 116, 2307-2311. https://doi.org/10.1016/j.sbspro.2014.01.564

Koutnikova, M. (2017). The application of comics in science education. Acta Educationis Generalis, 7(3), 88-95. https://doi.org/10.1515/atd-2017-0026

Lans, W., \& Van der Voordt, T.J.M. (2002). Ways to study. Descriptive research. In de Jong, T.M., \& Van der Voodrdt, T.J.M. (Eds.), Ways to study architectural, urban and technical design (53-60). Delft: DUP Science.

Murtiningrum, T., \& Ashadi, Mulyani, S. (2013). Pembelajaran kimia dengan problem solving menggunakan media e-learning dan komik ditinjau dari kemampuan berfikir abstrak dan kreativitas siswa. Jurnal Inkuiri, 2(3), 288-301.

Narayan, J.P. (2016). Textbook embedded contructivist pedagogy for effective and joyful learning. International Journal of Scientific Research and Education, 4(3), 5042-5049.

https://doi.org/10.18353/ijsre/v4i03.08

Naylor, S., \& Keogh, B. (2013). Concept cartoons: What have we learnt?. Journal of Turkish Science Education, 10(1), 3-11.

Noraini K. (2010). Kajian tinjauan secara kuantitatif. Dlm. Noraini Idris (Pnyt). Penyelidikan dalam pendidikan (pp. 195-214). Kuala Lumpur: Mc Graw-Hill (M) Sdn. Bhd.

Şahin, M. (2010). Effects of problem-based learning on university students' epistemological beliefs about physics learning and conceptual understanding of Newtonian Mechanics. Journal of Science Education and Technology, 19(3), 266-275. https://doi.org/10.1007/s10956-009-9198-7

Sockalingam, N., Rotgans, J., \& Schmidt, H.G. (2011). Student and tutor perceptions on attributes of effective problems in problem-based learning. Higher Education, 62(1), 1-16.

https://doi.org/10.1007/s10734-010-9361-3

Subhan, M., \& Lilia, H. (2010). Teachers' perception towards usage of cartoon in teaching and learning physics. Procedia - Social and Behavioral Sciences, 7, 538-545. https://doi.org/10.1016/j.sbspro.2010.10.072

Yin, Y.K., \& Fitzgerald, R. (2017). Peer learning with concept cartoons enhance critical thinking and performance in secondary school economics. Journal of Economic Education Research, 18(1), 1-13.

Published by OmniaScience (www.omniascience.com)

Journal of Technology and Science Education, 2019 (www.jotse.org)

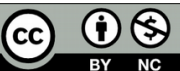

Article's contents are provided on an Attribution-Non Commercial 4.0 Creative commons International License. Readers are allowed to copy, distribute and communicate article's contents, provided the author's and JOTSE journal's names are included. It must not be used for commercial purposes. To see the complete licence contents, please visit https://creativecommons.org/licenses/by-nc/4.0/. 